\title{
Effect of Different Land Use Systems on Major Nutrient Status in Soils of Westernghat-Chikamagalur, Karnataka, India
}

\author{
K. M. Shivakumar ${ }^{1 *}$, S. S. Prakash ${ }^{2}$, M. S. Nagaraja ${ }^{3}$, \\ C. Vijay Kumar ${ }^{4}$ and Prabhudev Dhumgond ${ }^{2}$
}

${ }^{I}$ Department of Soil Science \& Agricultural Chemistry, College of Horticulture, Sirsi, UHS, Bagalkot, India

${ }^{2}$ Department of Soil Science \& Agricultural Chemistry, College of Agriculture, Mandya, UAS

Benegaluru, India

${ }^{3}$ Department of Soil Science \& Agricultural Chemistry, College of Agriculture, UAHS, Shivamogga, India

${ }^{4}$ ICAR-Krishi Vigyana Kendra, UAS Dharwad, India

*Corresponding author

\section{A B S T R A C T}

\section{Keywords}

Land use system, Soil fertility,

Nutrient dynamics, Major nutrients

Article Info

Accepted:

24 October 2020

Available Online:

10 November 2020
The present study was conducted to assess the impact of different land-use systems on major nutrient status viz: Nitrogen, Phosphorus and Potassium in soils of central part of Western ghat, Karnataka. The land use types include both manmade systems (Agriculture: paddy; Horticulture: coffee, are canut, tea and banana); forest plantation (accacia and teak) and natural systems (Evergreen, semi-evergreen and grassland). In each land use systems, samples were collected from two depths $(0-15 \mathrm{~cm}$ and $15-30 \mathrm{~cm})$ at 20 locations during pre-monsoon and post monsoon period. Soil samples were analyzed for available nitrogen, available phosphorus and available potassium. The results revealed that available nitrogen content in surface soil was significantly higher $\left(394.55 \mathrm{~kg} \mathrm{ha}^{-1}\right)$ than that of subsurface soil (330.57 kg ha $\left.{ }^{-1}\right)$. Among manmade land use systems, available nitrogen content was significantly higher in coffee $\left(435.82 \mathrm{~kg} \mathrm{ha}^{-1}\right)$ followed by in soils under banana $404.40 \mathrm{~kg}$ ha $^{-1}$. Similarly, natural system the available-N content was in the range of 294.97 to $376.55 \mathrm{~kg} \mathrm{ha}^{-1}$ with minimum in grassland and maximum in semi-evergreen forest. Available-P varied significantly among different land use systems. The highest available-P content was recorded in soils under coffee $\left(29.31 \mathrm{~kg} \mathrm{ha}^{-1}\right)$ followed by evergreen forest (28.37 $\left.\mathrm{kg} \mathrm{ha}^{-1}\right)$, semi-evergreen $\left(27.26 \mathrm{~kg} \mathrm{ha}^{-1}\right)$ and other systems. The available-P was least in grassland $\left(20.28 \mathrm{~kg} \mathrm{ha}^{-1}\right)$. The available $\mathrm{K}_{2} \mathrm{O}$ content in soils under paddy was $299.42 \mathrm{~kg} \mathrm{ha}^{-1}$ and it was significantly lower than other systems but was at par with those observed in grassland $\left(311.01 \mathrm{~kg} \mathrm{ha}^{-1}\right)$, acacia $\left(321.01 \mathrm{~kg} \mathrm{ha}^{-1}\right)$ and teak system $(329.86 \mathrm{~kg}$ $\left.\mathrm{ha}^{-1}\right)$. These results are indicated that well-managed horticultural system in general and coffee in particular had better soil fertility which is comparable to that found in natural forest system. 


\section{Introduction}

Soil degradation is a worldwide problem due to unscientific land use pattern and cropping techniques which attracted attention in sustainable agricultural production systems (Ayoubi, et al.,2011) The productivity and sustainability of soil depends on dynamic equilibrium among its physical, chemical, and biological properties (Somasundaram et al., 2013). These properties are continuously influenced by land use changes. According to Di et al., (2013), agricultural management practices can largely influence the quality of the soil which in turn is intrinsically linked to the sustainability of agro ecosystem functions and productivity. Therefore, successful agriculture requires the sustainable use of soil resources as soil could easily lose its quality and quantity within a short period of time (Kiflu and Beyene, 2013) Soil health maintenance is essential for sustained food productivity, the decomposition of wastes, storage of heat, sequestration of carbon, and the exchange of gases. Since 1945, it is estimated that $38 \%$ of the cultivated areas in the world have been degraded. Annually, approximately 24 billion tons of topsoil is lost, this is equivalent to about 9.6 million hectares of land. Therefore, soil degradation or changes in soil quality that result from wind and water erosion, salinization, losses of organic matter and nutrients, or soil compaction are of great concern in every agricultural region in the world.

The Western Ghats comprises an area of around 1, 60,000 $\mathrm{km}^{2}$, with an elevation ranges from $300-2700 \mathrm{~m}$ mean sea level. It covers 34 biodiversity hotspots of the world and are a chain of mountain ranges stretching north to south along the western peninsular India. The Western Ghats of Karnataka lies in southern states of India covers $20 \%$ of its geographical area, which receives an average annual rainfall of $>3500 \mathrm{~mm}$. Brown forest soils occur mainly in the Western Ghats under forests, in humid and sub-humid climate. They cover 6 per cent of the total geographical area of Karnataka and have developed on granites, gneisses and schists.

Soil fertility is a dynamic natural property and it can change under the influence of natural and human induced factors. Soil organic matter is an important factor in deciding management system of the forest soil fertility. The forest soils vary in physico-chemical changes with time and space resulting in variation among topography, climate, weathering processes, vegetation cover and microbial activities and also biotic and abiotic factors (Sannappa and Manjunath, 2013). Soil fertility fluctuates throughout the growing season each year due to land use changes and unscientific nutrient management practices by the addition of unbalanced fertilizers, manure, compost, mulch and lime in addition to leaching. Thus, the present study was taken up to evaluate the different land-use effects on soil fertility in soils of central parts westernghat of Karnataka was carried out to recommend appropriate soil conservation and land use management practices for sustainable agriculture.

\section{Materials and Methods}

\section{Study area}

A major watershed was selected for the study area in located in Chikamagalur district of western ghat of Karnataka, Chikamagalur district lies in between latitudes $12^{\circ} 54^{\prime} 42^{\prime \prime}$ to $13^{\circ} 53^{\prime} 53^{\prime \prime} \mathrm{N}$ and longitudes $75^{\circ} 04^{\prime} 46^{\prime \prime}$ to $76^{\circ} 21^{\prime} 15^{\prime \prime} \mathrm{E}$. Major part of the district is covered by mountains and there is a formidable ghats range in the west. The soil of this region mainly consists of Archaean schist and gneisses. The climate of the district is very pleasant and cool. April is generally the hottest month. The humidity is very high 
during the monsoon generally exceeding 90 per cent. The annual average rainfall of the district is 1000 to $2500 \mathrm{~mm}$. The drainage network is dense and areas are very deep, well drained, clay soils with moderately rapid permeability.

\section{Selection of land use system}

Major and important land use systems prevailing in the selected study area are broadly divided as manmade and natural systems. Manmade systems are further subdivided into agriculture, horticulture and forest plantation systems. Paddy represents agriculture system. While, areca nut, coffee, tea and banana constitute horticulture systems. Forest plantation systems comprise teak and acacia. While, natural system comprises of evergreen forest, Semievergreen forest and grassland system.

\section{Soil sample collection and analysis}

In each location for each land use system, a minimum of 8 to 10 spots were chosen in a sampling area (location) and samples from these spots were bulked to get one composite soil sample for one location. Eight such composite samples were collected for each land use system from two depths (0-15 and $15-30 \mathrm{~cm})$ during pre-monsoon season and post-monsoon season. Collected soil samples were analyzed for available nitrogen (Subbiah and Asija, 1956), available $\mathrm{P}_{2} \mathrm{O}_{5}$ (Bray and Kurtz, 1945), and available $\mathrm{K}_{2} \mathrm{O}$ (Jackson, 1973). Data obtained were subjected to statistical test using factorial completely randomized design (Sundararaj et al., 1972).

\section{Results and Discussion}

\section{Available nitrogen}

Nitrogen is essential for crop production as it is an important constituent of proteins, nucleic acids, porphyrins and alkaloids. SOM acts as a storehouse and supplier of $\mathrm{N}$ to plant roots and microorganisms, almost $95 \%$ of the total soil $\mathrm{N}$ is closely associated with SOM. Among the land use systems available-N content was significantly higher in coffee (435.82 $\mathrm{kg} \mathrm{ha}^{-1}$ ) followed by banana (404.40 $\left.\mathrm{kg} \mathrm{ha}{ }^{-1}\right)$ and arecanut $(362.32 \mathrm{~kg}$ $\mathrm{ha}^{-1}$ ) (Table 2). The variations in available-N may be attributed to variation in soil organic matter and total-N contents (Korikanthimath, 1994). Such variations in available-N for different land use systems are also reported by Stevenson (1994) and Nagaraja (1997). Continuous addition of organic matter is known to enhance both availability and totalN contents (Mukharjee and Ghosh, 1984 and Stangel et al., 1994). Secondly the buildup of available-N might be ascribed to the residual effect of applied $\mathrm{N}$ fertilizer and mineralization of FYM (Swarup Anand, 2001 and Uzma et al., 2009).

The higher available- $\mathrm{N}$ content in manmade system especially under coffee and banana might be attributed to application of very high dose of $\mathrm{N}$ fertilizers along with very high level of FYM. Similarly, the higher available$\mathrm{N}$ content under forest system was largely derived from mineralization of organic matter as these systems have not received $\mathrm{N}$ through external sources (Jordan, 1985; Dagar et al., 1995)

The higher available- $\mathrm{N}$ content under natural systems namely evergreen (385.07 $\mathrm{kg} \mathrm{ha}^{-1}$ ) and semi-evergreen (376.97 $\left.\mathrm{kg} \quad \mathrm{ha}^{-1}\right)$ compared to forest plantation systems viz., teak $\left(336.57 \mathrm{~kg} \mathrm{ha}^{-1}\right)$ and acacia $(353.81 \mathrm{~kg}$ $\mathrm{ha}^{-1}$ ) might be attributed to the variation in quality and quantity of litter as it is derived from mixed vegetation type under natural system. Secondly, the leguminous tree species in the natural forest might have fixed atmospheric N. Thus, the higher available-N content was observed under natural forest. 
The amount so fixed along $\mathrm{N}$ derived from mineralization might be sufficient to replace the $\mathrm{N}$ removed through the litter.

The difference in available nitrogen content with depth was significant. The soil available nitrogen content in surface soil was significantly higher $\left(394.55 \mathrm{~kg} \mathrm{ha}^{-1}\right)$ than that of subsurface soil ( $\left.330.57 \mathrm{~kg} \mathrm{ha}^{-1}\right)$ which may be attributed to accumulation of more organic matter on surface layer and its subsequent decomposition than the subsurface soil layer. These results are in conformity with the results obtained by Trevedi and Mishra (1985) explaining the presence of higher available nitrogen content in the surface layer than that of subsurface layer in a grassland ecosystem.

The available $\mathrm{N}$ content in soils collected during pre-monsoon season was $359.35 \mathrm{~kg}$ ha 1 and was lower than that observed during post-monsoon season (365.77 $\left.\mathrm{kg} \mathrm{ha}{ }^{-1}\right)$. However, the difference was not significant. This could be due to higher organic matter content of the soil contributing to higher available-N in the soil. Organic matter has always been considered as a good source of $\mathrm{N}$ in soil. The mineralization of organic matter releases significant amounts of $\mathrm{N}$ to the liable $\mathrm{N}$ pool (Ananth Kumar, 2011).

\section{Available phosphorus}

Phosphorus is known as the master key to agriculture production because lack of available $\mathrm{P}$ in the soils limits the growth of plants under both manmade and natural systems (Foth and Ellis, 1997).

The available- $\mathrm{P}_{2} \mathrm{O}_{5}$ status was significantly higher $\left(29.27 \mathrm{~kg} \mathrm{ha}^{-1}\right)$ in surface soil than that of subsurface soil (23.91 kg ha ${ }^{-1}$ ) (Table 3). In general, the highest available- $\mathrm{P}_{2} \mathrm{O}_{5}$ content was recorded in soils under coffee system (29.31 $\mathrm{kg} \mathrm{ha}^{-1)}$ followed by evergreen forest
(28.37 kg ha $\left.{ }^{-1}\right), \quad$ semi-evergreen $\quad(27.26$ $\left.\mathrm{kg} \mathrm{ha}^{-1}\right)$, teak $\left(27.17 \mathrm{~kg} \mathrm{ha}^{-1}\right)$, banana (26.79 $\mathrm{kg} \mathrm{ha}{ }^{-1}$ ), arecanut (26.01 $\mathrm{kg} \mathrm{ha}^{-1}$ ), acacia $\left(25.65 \mathrm{~kg} \mathrm{ha}^{-1}\right)$ and tea system $\left(24.81 \mathrm{~kg} \mathrm{ha}^{-1}\right)$, respectively. The available- $\mathrm{P}_{2} \mathrm{O}_{5}$ was lowest in grassland $\left(20.28 \mathrm{~kg} \mathrm{ha}^{-1}\right)$. This variation may be attributed to higher litter turnover and application of phosphatic fertilizer. These observations are in conformity with the findings of Anil Kumar (2002); Hariyappa et al., (2009) and Niranjana et al., (2009). Such accumulations of $\mathrm{P}$ due to addition of fertilizers were also reported by Nagaraja (1997) and Chang et al., (2008).

The higher available- $\mathrm{P}_{2} \mathrm{O}_{5}$ in manmade systems might be attributed to supplementation through external source. In agricultural soils, $\mathrm{P}$ application and its use efficiency appear to be important in regulating $\mathrm{P}$-accumulation. Thus, lower $\mathrm{P}$-use efficiency would lead to its accumulation in both agricultural and horticultural systems (Nambiar, 1994; Powlson and Johnston, 1994). This may be the reason for higher available- $\mathrm{P}_{2} \mathrm{O}_{5}$ under coffee. Lower availability of phosphorus in forest systems compared to coffee systems clearly demonstrates that the soils in this region are P-deficient. Acidic soil $\mathrm{pH}$ associated with higher $\mathrm{Fe}$ and $\mathrm{Al}$ activities in Alfisols might have reduced its availability (Tan, 2010).

The seasonal changes in available- $\mathrm{P}_{2} \mathrm{O}_{5}$ content were significant and the values 26.50 $\mathrm{kg} \mathrm{ha}{ }^{-1}$ during pre-monsoon season significantly higher than that observed during post-monsoon season $\left(25.41 \mathrm{~kg} \mathrm{ha}^{-1}\right)$. This might have been the consequence of soil $\mathrm{pH}$ which was relatively lower in the postmonsoon season favouring the $\mathrm{P}$ fixation (Ravi and Ananthanarayan, 1997). At low soil $\mathrm{pH}, \mathrm{P}$ may be fixed as iron and aluminium phosphate, which are not likely to be readily available to plants (Ananth Kumar, 2011). 
Table.1 Description of vegetation and management practices followed in different land use systems

\begin{tabular}{|c|c|c|c|c|}
\hline \multirow[t]{2}{*}{ Land use system } & \multirow{2}{*}{$\begin{array}{c}\text { Type of system } \\
\text { natural / man } \\
\text { made }\end{array}$} & \multicolumn{3}{|c|}{ Management } \\
\hline & & Irrigation & $\begin{array}{c}\text { Source of external } \\
\text { nutrient input }\end{array}$ & Produce \\
\hline \multicolumn{5}{|l|}{ I. Manmade } \\
\hline \multicolumn{5}{|l|}{ (a)Agriculture } \\
\hline Paddy & Man made & Irrigated & Fertilizer $+\mathrm{FYM}$ & Stubbles and roots \\
\hline \multicolumn{5}{|l|}{ (b) Horticulture } \\
\hline Arecanut & Man made & Drip/Nil & Fertilizer + FYM & Fronds/grass \\
\hline Coffee & Man made & Drip/Nil & Fertilizer + FYM & Litter \\
\hline Tea & Man made & Drip/ Nil & Fertilizer + FYM & Litter \\
\hline Banana & Man made & Drip/Irrigated & Fertilizer. + FYM & Leaves/stems /grass \\
\hline \multicolumn{5}{|l|}{ (c) Forest plantation } \\
\hline Teak & Man made & Nil & Nil & Litter \\
\hline Acacia & Man made & Nil & Nil & Litter \\
\hline \multicolumn{5}{|l|}{ II. Natural forest } \\
\hline Evergreen forest & Natural & Nil & Nil & Litter \\
\hline $\begin{array}{l}\text { Semi-evergreen } \\
\text { forest }\end{array}$ & Natural & Nil & Nil & Litter \\
\hline Grassland & Natural & Nil & Nil & Roots/litter \\
\hline
\end{tabular}

Table.2 Available nitrogen $\left(\mathrm{kg} \mathrm{ha}^{-1}\right)$ status in soils of different land use systems during pre and post monsoon seasons

\begin{tabular}{|c|c|c|c|c|c|c|c|}
\hline \multirow[t]{3}{*}{ Land use systems } & \multicolumn{3}{|c|}{ Pre-monsoon } & \multicolumn{3}{|c|}{ Post-monsoon } & \multirow{3}{*}{$\begin{array}{l}\text { Mean of } \\
\text { systems }\end{array}$} \\
\hline & \multicolumn{2}{|c|}{ Depth(cm) } & \multirow[t]{2}{*}{ Mean } & \multicolumn{2}{|c|}{$\operatorname{Depth}(\mathrm{cm})$} & \multirow[t]{2}{*}{ Mean } & \\
\hline & $0-15$ & $15-30$ & & $0-15$ & $15-30$ & & \\
\hline Paddy & 349.58 & 263.72 & 306.65 & 402.30 & 385.00 & 393.65 & 350.15 \\
\hline Arecanut & 455.40 & 332.76 & 394.08 & 340.72 & 320.39 & 330.56 & 362.32 \\
\hline Coffee & 482.74 & 395.92 & 439.33 & 466.49 & 398.12 & 432.30 & 435.82 \\
\hline Tea & 397.18 & 309.27 & 353.23 & 361.52 & 289.47 & 325.49 & 339.36 \\
\hline Banana & 385.25 & 323.53 & 354.39 & 485.12 & 423.70 & 454.41 & 404.40 \\
\hline Teak & 391.77 & 315.85 & 353.81 & 378.30 & 323.31 & 350.80 & 352.31 \\
\hline Acacia & 375.52 & 297.62 & 336.57 & 363.80 & 330.12 & 346.95 & 341.76 \\
\hline Evergreen forest & 446.22 & 323.91 & 385.07 & 299.67 & 312.89 & 306.28 & 345.67 \\
\hline $\begin{array}{l}\text { Semi-evergreen } \\
\text { forest }\end{array}$ & 440.18 & 326.14 & 383.16 & 402.02 & 337.87 & 369.95 & 376.55 \\
\hline Grassland & 318.92 & 255.58 & 287.25 & 348.41 & 256.98 & 302.70 & 294.97 \\
\hline Mean of season & \multicolumn{3}{|c|}{359.35} & \multicolumn{4}{|c|}{365.77} \\
\hline \multirow[t]{3}{*}{ Mean of depth } & \multicolumn{3}{|c|}{$0-15 \mathrm{~cm}$} & \multicolumn{4}{|c|}{$15-30 \mathrm{~cm}$} \\
\hline & \multicolumn{3}{|c|}{394.55} & \multicolumn{4}{|c|}{330.57} \\
\hline & $\begin{array}{l}\text { L (Land } \\
\text { use) }\end{array}$ & $\begin{array}{c}\text { D } \\
\text { (Depth) }\end{array}$ & $\begin{array}{c}\text { S } \\
\text { (Season) }\end{array}$ & $\mathbf{S} \times \mathbf{D}$ & $\mathbf{L} \times \mathbf{D}$ & $\mathbf{S} \times \mathbf{L}$ & $\mathbf{S} \times \mathbf{L} \times \mathbf{D}$ \\
\hline S.Em \pm & 9.31 & 4.16 & 4.16 & 5.89 & 13.17 & 13.17 & 18.63 \\
\hline CD@ $5 \%$ & 25.94 & 11.60 & NS & 16.40 & NS & 36.68 & 51.87 \\
\hline
\end{tabular}


Table.3 Available- $\mathrm{P}_{2} \mathrm{O}_{5}\left(\mathrm{~kg} \mathrm{ha}^{-1}\right)$ status in soils of different land use systems during pre and post monsoon seasons

\begin{tabular}{|c|c|c|c|c|c|c|c|}
\hline \multirow[t]{3}{*}{ Land use systems } & \multicolumn{3}{|c|}{ Pre-monsoon } & \multicolumn{3}{|c|}{ Post-monsoon } & \multirow{3}{*}{$\begin{array}{l}\text { Mean of } \\
\text { systems }\end{array}$} \\
\hline & \multicolumn{2}{|c|}{ Depth (cm) } & \multirow[t]{2}{*}{ Mean } & \multicolumn{2}{|c|}{$\operatorname{Depth}(\mathrm{cm})$} & \multirow[t]{2}{*}{ Mean } & \\
\hline & $0-15$ & $15-30$ & & $0-15$ & $15-30$ & & \\
\hline Paddy & 26.43 & 20.81 & 23.62 & 25.99 & 20.68 & 23.34 & 23.48 \\
\hline Arecanut & 30.33 & 21.74 & 26.03 & 28.54 & 23.42 & 25.98 & 26.01 \\
\hline Coffee & 34.31 & 22.91 & 28.61 & 34.59 & 25.42 & 30.00 & 29.31 \\
\hline Tea & 26.77 & 23.31 & 25.04 & 25.82 & 23.34 & 24.58 & 24.81 \\
\hline Banana & 30.99 & 24.02 & 27.51 & 29.16 & 22.99 & 26.07 & 26.79 \\
\hline Teak & 28.10 & 28.34 & 27.22 & 28.00 & 26.15 & 27.17 & 27.17 \\
\hline Acacia & 25.23 & 25.56 & 25.40 & 25.67 & 26.15 & 25.65 & 25.65 \\
\hline Evergreen forest & 35.12 & 24.49 & 29.80 & 29.74 & 24.15 & 26.94 & 28.37 \\
\hline Semi-evergreen forest & 34.57 & 25.00 & 29.78 & 27.55 & 21.94 & 24.75 & 27.26 \\
\hline Grassland & 23.76 & 18.36 & 21.06 & 22.07 & 16.94 & 19.50 & 20.28 \\
\hline Mean of season & \multicolumn{3}{|c|}{26.50} & \multicolumn{4}{|c|}{25.41} \\
\hline \multirow[t]{3}{*}{ Mean of depth } & \multicolumn{3}{|c|}{$0-15 \mathrm{~cm}$} & \multicolumn{4}{|c|}{$15-30 \mathrm{~cm}$} \\
\hline & \multicolumn{3}{|c|}{29.27} & \multicolumn{4}{|c|}{23.91} \\
\hline & $\begin{array}{l}\text { L (Land } \\
\text { use) }\end{array}$ & $\begin{array}{c}\text { D } \\
\text { (Depth) }\end{array}$ & $\begin{array}{c}\mathrm{S} \\
\text { (Season) }\end{array}$ & $\mathbf{S} \times \mathbf{D}$ & $\mathbf{L} \times \mathbf{D}$ & $\mathbf{S} \times \mathbf{L}$ & $\mathbf{S} \times \mathbf{L} \times \mathbf{D}$ \\
\hline S.Em \pm & 0.80 & 0.36 & 0.36 & 0.50 & 1.13 & 1.13 & 1.59 \\
\hline CD@ $5 \%$ & 2.22 & 0.99 & 0.99 & 1.40 & NS & NS & NS \\
\hline
\end{tabular}

Table.4 Available- $\mathrm{K}_{2} \mathrm{O}\left(\mathrm{kg} \mathrm{ha}^{-1}\right)$ status in soils of different land use systems during pre and postmonsoon seasons

\begin{tabular}{|c|c|c|c|c|c|c|c|}
\hline \multirow[t]{3}{*}{ Land use systems } & \multicolumn{3}{|c|}{ Pre-monsoon } & \multicolumn{3}{|c|}{ Post-monsoon } & \multirow{3}{*}{$\begin{array}{c}\text { Mean of } \\
\text { systems }\end{array}$} \\
\hline & \multicolumn{2}{|c|}{ Depth $(\mathbf{c m})$} & \multirow{2}{*}{ Mean } & \multicolumn{2}{|c|}{ Depth $(\mathrm{cm})$} & \multirow{2}{*}{ Mean } & \\
\hline & $0-15$ & $15-30$ & & $0-15$ & $15-30$ & & \\
\hline Paddy & 360.25 & 243.18 & 301.71 & 333.46 & 260.78 & 297.12 & 299.42 \\
\hline Arecanut & 479.26 & 335.13 & 407.19 & 475.30 & 347.10 & 411.20 & 409.20 \\
\hline Coffee & 527.50 & 434.07 & 480.78 & 543.60 & 453.60 & 498.60 & 489.69 \\
\hline Tea & 374.33 & 305.60 & 339.97 & 388.79 & 323.89 & 356.34 & 348.15 \\
\hline Banana & 404.15 & 317.67 & 360.91 & 405.12 & 339.18 & 372.15 & 366.53 \\
\hline Teak & 408.31 & 276.07 & 342.19 & 358.99 & 276.09 & 317.54 & 329.86 \\
\hline Acacia & 354.52 & 294.49 & 324.51 & 350.02 & 285.02 & 317.52 & 321.01 \\
\hline Evergreen forest & 449.30 & 321.50 & 385.40 & 360.69 & 321.96 & 341.32 & 363.36 \\
\hline $\begin{array}{l}\text { Semi-evergreen } \\
\text { forest }\end{array}$ & 454.24 & 367.88 & 411.06 & 353.90 & 324.54 & 339.22 & 375.14 \\
\hline Grassland & 347.55 & 291.84 & 319.69 & 316.21 & 288.46 & 302.33 & 311.01 \\
\hline Mean of season & \multicolumn{3}{|c|}{367.34} & \multicolumn{4}{|c|}{355.33} \\
\hline \multirow[t]{3}{*}{ Mean of depth } & \multicolumn{3}{|c|}{$0-15 \mathrm{~cm}$} & \multicolumn{4}{|c|}{$15-30 \mathrm{~cm}$} \\
\hline & \multicolumn{3}{|c|}{402.27} & \multicolumn{4}{|c|}{320.40} \\
\hline & $\begin{array}{l}\text { L (Land } \\
\text { use) }\end{array}$ & $\begin{array}{c}\text { D } \\
\text { (Depth) }\end{array}$ & $\begin{array}{c}\mathbf{S} \\
\text { (Season) }\end{array}$ & $\mathbf{S} \times \mathbf{D}$ & $\mathbf{L} \times \mathbf{D}$ & $\mathbf{S} \times \mathbf{L}$ & $\mathbf{S} \times \mathbf{L} \times \mathbf{D}$ \\
\hline S.Em \pm & 12.17 & 5.44 & 5.44 & 7.70 & 17.21 & 17.21 & 24.34 \\
\hline CD@ $5 \%$ & 33.88 & 15.15 & NS & 21.43 & NS & NS & NS \\
\hline
\end{tabular}




\section{Available potassium}

Potassium is the third most important essential element next to $\mathrm{N}$ and $\mathrm{P}$ that limit plant productivity. Its behaviour in the soil is influenced primarily by soil cation exchange properties and mineral weathering rather than by microbiological processes. (Brady and Weil, 1996)

The highest available $\mathrm{K}_{2} \mathrm{O}$ content of 489.69 $\mathrm{kg} \mathrm{ha}{ }^{-1}$ was found in soil under coffee followed by soils under arecanut $(409.20 \mathrm{~kg}$ $\mathrm{ha}^{-1}$ ) systems compared to other systems (Table 4). The higher available $\mathrm{K}_{2} \mathrm{O}$ status in these soils might be due to addition of potassic fertilizers at very high levels over the years. Accumulation of potassium in horticultural systems due to excess application of potassic fertilizer. Secondly, the higher available $\mathrm{K}_{2} \mathrm{O}$ status might be due to higher turnover of litter and its subsequent decomposition. Similar results were reported by Anil Kumar (2002); Shilpashree et al., (2011); Sharan Bhoopal Reddy (2010) and Ananth Kumar (2011).

The available $\mathrm{K}_{2} \mathrm{O}$ content was relatively low in forest systems compared to that of horticulture systems mainly because of nonapplication of potassic fertilizers and also due to lower mineralization process. Further, the potassium content in forest litter was lower than that of coffee might have been contributed to lower available $\mathrm{K}_{2} \mathrm{O}$ status in forest soils. Secondly the surface added $\mathrm{K}_{2} \mathrm{O}$ through the litter decomposition might have lost by leaching (Rudramurthy et al., 2007 and Ananthanarayana and Ravi (1997).

Available $\mathrm{K}_{2} \mathrm{O}$ content of soil was relatively higher in pre-monsoon season $(367.34 \mathrm{~kg} \mathrm{ha}$ $\left.{ }^{1}\right)$ as compared to post-monsoon season $\left(355.33 \mathrm{~kg} \mathrm{ha}^{-1}\right)$ in all the systems this could be due to higher soil organic matter content contributing to higher available $\mathrm{K}_{2} \mathrm{O}$ in the pre-monsoon season. The reduction in available $\mathrm{K}_{2} \mathrm{O}$ in post-monsoon may be due to leaching during rainy period (Ananth Kumar, 2011).

In conclusion the land use system influences soil nutrient status. Accordingly, well managed horticultural system particularly coffee had better soil nutrient status compared to natural forest system, paddy, grassland and manmade forest plantation. Variation of nitrogen, phosphorus and potassium among different land use systems were minimal on lower soil layer as compared to the surface soil layer, implying that surface soil layer is most affected by different management practices. On the basis of the above findings, there is a need to develop proper land use policy and sustainable soil management and cropping practices to improve soil fertility and combat the on going soil degradation in the study area.

\section{References}

Ananth Kumar, M.A., 2011, Soil properties and dynamics of major nutrients in soils as influenced by shade trees, rainfall pattern and nutrient management in coffee growing areas of Karnataka. Ph. D. Thesis, submitted to Univ. Agric. Sci., Bangalore.

Ananthanarayanaya, R. and Ravi, M.V., 1997, Nature of soil acidity of coffee growing soils of Karnataka. J. Indian Soc. Soil Sci., 45(2): 384-385.

Anilkumar, K.S., 2002, Characterization, classification and suitability evaluation of coffee growing soils of Karnataka. $\mathrm{Ph}$. D. Thesis, submitted to Univ. Agric. Sci., Bangalore

Ayoubi, S. Khormali, F. Sahrawat, K. L. and Rodrigues, 2011, "Assessing impacts of land use change on soil quality indicators in a loessial soil in Golestan province, Iran," J. Agril Sci. and Tech, 
13: 727-742.

Bray, R. H. and Kurtz, L. T., 1945, Determination of total, organic and available forms of phosphorus in soils. Soil Sci., 59: 39-45.

Chang, E.H., Chung, R.S. and Wang, F.N., 2008. Effect of different types of organic fertilizers on the chemical properties and enzymatic activities of an Oxisol under intensive cultivation of vegetables for 4 years. Soil Sci. Pl. Nutr., 54: 587-599.

Dagar, J.C., Mongia, A.D. and Singh, N.T., 1995, Degradation of tropical rain forest soils upon replacement with plantation and arable crops in Andaman and Nicobar Islands in India. Trop. Ecol., 36: 89-102.

Di, H. J., Cameron, K. C and Shen, J. 2013.The role of bacteria and archaea in nitrification, nitrate leaching and nitrous oxide emissions in nitrogenrich grassland soils," in Molecular Envi. Soil Science, $\mathrm{Xu}$ and D. L. Sparks, Eds., pp. 79-89,

Foth, H.D. and Ellis, B.G., 1997, Soil fertility, 2nd Ed. Lewis CRC Press LLC., USA, 290.

Hariyappa, N., Violet D'souza, M., Nagaraj, J.S., Ananthakumar, M.A. and Jayarama, 2009, Status of available major and micronutrients in the coffee soils of Chikmagalur district in Karnataka. J. Plantation Crops, 17(3): 232-234.

Jackson, M. L., 1973, Soil Chemical Analysis, Prentice Hall of India Private Limited, New Delhi.

Korikanthimath, V. S,. 1994, Nutrition of cardamom. Adv. Hort., 9: 467-476.

Menta, C., 2012, Soil fauna diversityfunction, soil degradation, biological indices, soil restoration," in Biodiversity Conservation and Utilization in a Diverse World, G. A. Lameed, Ed., Intech Open, London,
UK.

Mukharjee, S.K. and Ghosh, K., 1984, Chemistry of soil organic matter in relation to soil nitrogen availability. Bull. Indian Soc. Soil Sci., 13: 20-29.

Nagaraja, M.S., 1997, Biomass turnover, nutrient status and biological process in different land use systems. Ph. D. Thesis submitted to Univ. Agril. Sci., Bangalore.

Nambiar, I.P.S., Marykutty, K.C., Balakrishnan, S., Pillai, M.R.C. and Nair, M.C.N., 1979, Effect of split application of $\mathrm{N}$ and $\mathrm{K}$ on banana var. Nendran. Agric. Res. J. Kerala, 17(2): 275-277.

Niranjana, K.V., Vadivelu, S., Maria Violet D'souza, Nagaraj, J. S., Arti Koyal and Ramesh, M., 2009, Soils of coffee growing areas of Western Ghats in Chikmagalur district of Karnataka. $J$. Coffee Res., 37(1\&2): 1-9.

Oguike P. C. and. Mbagwu, J. S. C 2009 "Variations in some physical properties and organic matter content of soils of coastal plain sand under different land use types," World J. Agril Sci., 5(1): 63-69.

Powlson, D.S. AND Johnston, A.E., 1994, Long term field experiments: Their importance in understanding sustainable agriculture. In D. J. Greenland and I. Szabolcs (eds), Soil Resilience and Sustainable Land Use, $\mathrm{CAB}$ International, Oxon, UK. pp. 422-451.

Rudramurthy, H.V., Puttaiah, E.T. and Vageesh, T.S., 2007, Chemical properties of soils under different land use systems in Shimoga district of Karnataka. J. Indian Soc. Soil Sci., 55(3): 259-264.

Sharan Bhoopal Reddy, 2010, Characterization of humic fractions and their relationship to soil quality parameters under different land use 
systems of Hassan district. M.Sc (Agri). Thesis, submitted to Univ. Agric. Sci., Bangalore.

Shilpashree, Y.P., Narayana, J., Anilkumar, Talageri, D., Vishwanath Shetty, Y. and Satish, C., 2011, Nutrient status in arecanut garden soils of Shimoga and Bhadravathi taluk. Plant Archive, 11(1): 429-430.

Somasundaram, J. R. K. Singh, A. K. and Parandiyal, 2013. Soil properties under different land use systems in parts of Chambal region of Rajasthan, J. Agril. Phy. 13(2): pp. 139-147.

Stangel, P., Pier, C and Mokwunye, U., 1994, Maintaining nutrient status of soils: Macronutrients. In D.J. Greenland and I. Szabolcs (eds) Soil Resilience and Sustainable Land, CAB International, Oxon, UK. pp. 171-198.

Stevenson, F.J., 1994, Humus chemistrygenesis, composition, reactions. Wiley, New York.

Subbaiah, B. V. and Asija, G. L., 1956, A rapid procedure for the estimation of available nitrogen in soils. Current Science, 25:259-260.

Sundararaja, N., Nagaraju, S., Venkata Ramu, M.N. and Jagannath, M.K., 1972, Design and analysis of field experiments, UAS, Hebbal, Bangalore.

Swarup Anand, 2001, Effects of integrated nutrient management on soil properties and yield of rice in Alkali soils. $J$. Indian Soc. of Soil Sci., 11: 3-5.

Tan, K. H., 2010, Principles of Soil Chemistry. CRC Press. Ltd., pp. 488.

Uzma, B., Fozia, Q., Suja, Q. and Subhash Chand, 2009, Influence of nitrogen and FYM on growth, yield and nutrient use efficiency in potato, Indian J. Fert., 5(11): 67-70.

Zhou, W. lv, T. F., Chen, Y., Westby A. P. and. Ren, W. J., 2014 "Soil physicochemical and biological properties of paddy-upland rotation: a review," Scientific World J, (2014) 856352, 8 pages, 2014.

\section{How to cite this article:}

Shivakumar, K. M., S. S. Prakash, M. S. Nagaraja, C. Vijay Kumar and Prabhudev Dhumgond. 2020. Effect of Different Land Use Systems on Major Nutrient Status in Soils of WesternghatChikamagalur, Karnataka, India. Int.J.Curr.Microbiol.App.Sci. 9(11): 3502-3510. doi: https://doi.org/10.20546/ijcmas.2020.911.418 